\title{
THE HOSPITALS OF LATER MEDIEVAL LONDON
}

by

\section{CAROLE RAWCLIFFE}

IN her study of the medieval hospitals of England, composed at the beginning of this century, Rotha M. Clay drew attention to the involvement of municipal and civic authorities throughout the country in the endowment and management of hospitals run for the benefit of the local community. "It was", she wrote, "undoubtedly the townsfolk who were the principal founders of the fourteenth and fifteenth centuries"; and foremost among them were the "old merchant princes" such as Richard Whittington and William Elsyng, whose munificence led to the foundation of particularly impressive institutions in the capital. ${ }^{2}$ When viewed as a whole, the hospitals of later medieval London are comparatively better documented than those in other parts of England, but despite this fact, very little research beyond individual monographs has been done to examine in detail how these bodies were organized or, indeed, what part the more affluent freemen played in the provision of medical care and alms for the sick poor. Notwithstanding the recent interest shown by scholars in the administration of relief and welfare services after the Reformation, the preceding centuries have been largely neglected, and the important contribution made by Londoners in this field before the 1530 s tends to be undervalued as a result. This is all the more unfortunate, because since Miss Clay's work appeared in 1909 large quantities of source material concerning London and its hospitals have become readily accessible in the form of calendars and editions of both civic and national records. Secondary works on London history have also been produced in considerable numbers; and it is now possible to show not only how far the citizenry were instrumental in founding hospitals and almshouses, but also the extent to which they attempted to reform abuses arising from the lack of administrative and financial expertise on the part of the religious authorities. Although very much concerned with these two questions, this paper also provides a general discussion of the work and functions of London's hospitals, again because so much new and hitherto unused evidence has come to light.

Unlike its modern-day counterpart, the medieval hospital was not merely an institution for the care of the sick: and although this aspect of its work came to assume particular significance, it is important to recognize the wide range of purely social functions that even quite small foundations discharged during the two or three

\footnotetext{
' Carole Rawcliffe, PhD, FRHistS, 24 Villiers Road, London NW2 5PH. I am particularly grateful to Dr Caroline Barron of Bedford College, London University, and Miss Margaret Condon of the Public Record Office for the help which they have given me in writing this article.
}

${ }^{2}$ Rotha M. Clay, The medieval hospitals of England, London, Methuen, 1909, p. 81. 


\section{Carole Rawcliffe}

centuries before the Reformation. ${ }^{3}$ In keeping with the long-established monastic traditions to which most houses were heir, hospitality, albeit of an often rudimentary kind, was offered to travellers of all classes. The demand for temporary board and lodging was nowhere greater than in London; and a constant stream of wayfarers passed through the City's major hospitals, sometimes diverting the brethren from their spiritual and charitable duties. St Bartholomew's Hospital prided itself upon the warmth and scope of its hospitality, which was indeed such that in 1464 the king pardoned certain unauthorized grants to the house in consideration of the relief given there "to poor pilgrims, soldiers, sailors and others of all nations".4 To supplement their funds, some institutions were even prepared to offer semi-permanent accommodation, often to widows or women whose husbands had gone abroad. In July 1383, for example, the prior of St Mary's Hospital without Bishopsgate sued Sir Robert Aleyn for a debt of $£ 19$ incurred by his wife during her time as a boarder. Most of the money was owed for food, such as the two loaves, two gallons of beer, and two "dishes of cookery" which she and her servants had consumed daily throughout the summer of 1378 , although she had also borrowed money from the prior at various times. ${ }^{3}$ So far as we know, Lady Aleyn had at least behaved with propriety while living in the hospital, but not all guests were above reproach. If we are to believe the testimony of the plaintiffs in a case of disputed dower which reached the courts in 1369, Joan, the widow of Robert Fuwyth, had not only conspired with her lover to assault and rob her former husband, but had also absconded with him to live in adultery at St Thomas's Hospital, Southwark. Joan claimed, somewhat implausibly, to have been abducted without her consent and to have escaped from the hospital at the first opportunity, but either way the evidence raises some interesting questions about the type of people who gained admittance there. ${ }^{6}$

The two city hospitals of St Anthony and St Bartholomew, on the other hand, were noted for their high standards, especially as educational establishments. St Bartholomew's (which lay near the stews in Cock Lane, Smithfield) provided special facilities for the unmarried mother, who was allocated "mete and drynke of the placys coste and full honestely gydyd and kept" for some weeks after giving birth. Her child was customarily cared for only until it was weaned, but if, as often happened, she died, the infant became eligible for full board and education at the hospital's expense. The brethren also rescued babies from Newgate prison; and they, too, received free tution as a matter of course. These poor and orphaned children formed the nucleus of a school which achieved such good results that it soon began to attract fee-paying pupils from outside. As early as 1260 , for instance, the widow of Walter de Chaure, acting on the advice of friends and neighbours, gave the hospital her husband's houses in Smithfield to finance the education of her two sons.' Even more celebrated was the

\footnotetext{
${ }^{3}$ For a comprehensive contemporary list of these functions see Robert Copland, The hye way to the spytell house, London, 1536, ff. $4 \mathrm{v}-5$.

4 Calendar of patent rolls, 1461-1467, London, HMSO, 1897, p. 323.

${ }^{3}$ Arthur H. Thomas (editor), Calendar of select pleas and memoranda of the City of London, 1381-1412, Cambridge University Press, 1932, pp. 47-49.

- George Wrottesley, 'Extracts from the plea rolls of the reigns of Edward III and Richard II', William Salt Archaeol. Soc., 1892, 13: 76.

'Nellie J. M. Kerling (editor), The cartulary of St. Batholomew's hospital, London, Lund Humphries, 1973, p. 9; Clay, op. cit., note 2 above, pp. 7-9; James Gairdner (editor), The historical collections of $a$
} 


\section{The hospitals of later medieval London}

grammar school of St Anthony's Hospital, which blossomed under royal and civic patronage in the mid-fifteenth century. In May 1446, Henry VI assented to an ordinance of the Archbishop of Canterbury that there should be only five approved grammar schools in London, one of which was to be St Anthony's. The pupils received a thorough grounding in music, and it is probably no coincidence that in 1469 the king's minstrels set up a fraternity in the hospital church. By 1522, the staff included a schoolmaster, a master of the song school, seven clerks, and an usher. Some almsgiving was still carried out, but the brethren had by then abandoned their medical work, devoting themselves almost exclusively to the care of their young charges. ${ }^{8}$ This was likewise the case at the hospital of St Katherine near the Tower, which, from 1273 onwards, gave up general nursing to continue under a new charter as an almshouse for eighteen bedeswomen and six poor scholars.' Hospital schools often proved a useful means of augmenting otherwise meagre resources; and the temptation to neglect the less lucrative but socially far more necessary aspects of their work in the interests of turning a quick profit led some authorities to recruit pupils at the direct expense of the sick and destitute. This happened at the Bethlehem hospital during the late fourteenth century, when the deputy warden deprived the inmates of food, fuel, and supplies so that he could equip a school for fee-paying boys. ${ }^{10}$

The most important, and indeed the most specialized, function carried out by the medieval hospital was that of looking after the old, poor, and sick, who could not otherwise support themselves. In principle, this had to be done without charge, and many surviving hospital statutes refer specifically to the sacred obligation of providing free succour for the needy: but in practice, attitudes were often modified by pressing economic circumstances. Those who could do so generally made some contribution towards their upkeep and nursing, either by paying cash or reaching some alternative arrangement with the authorities. Thus, elderly people no longer able to manage without help made over their property in reversion to St Bartholomew's Hospital in return for a promise of aid from the brethren, who undertook to care for them in their own homes for as long as possible before receiving them into the infirmary itself. ${ }^{11}$ The purchase of corrodies, whereby an individual was assured of board and lodging for life upon payment of a specific sum of money, was a common and much-criticized feature of the medieval hospital; but although the practice diverted food, drink, and accommodation from those who had the most need of it, the corrodiary was, at least,

citizen of London in the fifteenth century, London, Camden Society, 1876, new series vol. 17, p. ix.

- William Page (editor), The Victoria county history of London, London, Constable, 1909, p. 582; Calendar of patent rolls, 1441-1446, London, HMSO, 1908, pp. 43, 432.

- Catherine Jamison, The history of the royal free hospital of St. Katherine by the Tower of London, Oxford University Press, 1952, p. 28. At the Reformation, each of the six scholars received an allowance of $£ 4$ a year for their upkeep, and the schoolmaster one of $£ 8$ (Letters and papers foreign and domestic, Henry VIII, 21 vols., London, HMSO, 1864-1920, vol. 9, (ed. James Gairdner), appendix 13, p. 407). At the hospital of St Thomas Acon, revenues of $£ 917 \mathrm{~s}$. 8d. were set aside for "exhibitioners and boys" (Public Record Office (PRO), E135/2/57 f. 2v).

10 PRO, C270/22 m. 2.

${ }^{11}$ Kerling (editor), op. cit., note 7 above, p. 9. Similarly, in 1253, the widowed Alice de Chalvedon made over all her lands in Chaldon to St Thomas's Hospital, Southwark, on the condition that she would have a "suitable bed" there for life, together with all reasonable necessities for herself and a maid, plus $5 s$. $6 d$. a year for clothing and food (British Library, Stowe MS. 942 ff. 272-273). 


\section{Carole Rawcliffe}

required to do what he could in procuring funds and support for the house. ${ }^{12}$ The greatest evil lay in the use of such pensions by either the Crown or other monastic patrons as a means of rewarding old retainers, for in this case the hospital coffers derived no benefit at all, while the resources were still depleted. In his 1316 visitation of St Bartholomew's, the Bishop of London condemned the great diminution of hospital funds through the reckless granting out of corrodies, and forbade any such alienations in future without his consent. The same complaint was reiterated even more forcibly in 1387 by the Bishop of Winchester, this time with regard to $\mathrm{St}$ Thomas's, Southwark, where he found that the endowment had been dissipated and the poor deprived of their rightful maintenance. ${ }^{13}$

It is now impossible to give any hard and fast rules about the scale of fees imposed by London hospitals upon their more affluent patients, since rates varied considerably according to the relative wealth of the individual and the financial state of the house in which he found himself. An inquiry into the administration of St Mary's Bethlehem made in 1403 reveals that a general fee of $6 s .8 d$. per quarter was then being charged, but that modest reductions were available for long-term patients detained for two years or more. The hospital had already begun to specialize in the care of the insane, and one of the inmates at this time, who was evidently suffering from some form of mental disturbance, had actually been kept there through the generosity of her neighbours for over one and a half years in the hope that she might recover her reason. ${ }^{14}$ Other factors, besides the preferential treatment accorded to fee-payers, contributed towards the general erosion of resources that ought properly to have been available for the truly deserving. Pre-Reformation, and especially Lollard, literature abounds in complaints about the abuse of poor relief by "sturdy beggars" who made a veritable profession of indigence. One city merchant was so exercised on this point that he specifically excluded "the commyn beggeres going aboute all the daie light and lying in [hospitals] the nyght tyme" from a bequest of $£ 26.8 \mathrm{~s}$. $4 \mathrm{~d}$. made in 1479 to the "poure bedred" of London's four major hospitals, insisting that alms should be given "butt to the veray needy lakkyng frendeship, comfort and help". ${ }^{15}$ His sentiments were echoed repeatedly by the civic community during our period, although little was done in practical terms to ensure that relief was expended in the right quarter.

In their survey of medieval religious houses in England and Wales, David Knowles and Neville Hadcock list twenty-five almshouses and hospitals of pre-Reformation date in the City of London itself, although Robert Denton's plan for the capital's first lunatic asylum remained a pious hope which never materialized. To this number must be added St Thomas's Hospital, Southwark, a small house dedicated to Our Lady and St Katherine at Newington, two equally modest foundations at Bermondsey, and a rather obscure hospital in St Andrew's parish, Holborn. Westminster possessed two almshouses and a hospice in the precincts of the royal palace; and nearby at Charing

${ }^{12}$ Calendar of patent rolls, 1388-1392, London, HMSO, 1902, p. 484.

13 Victoria county history of London, op. cit., note 8 above, p. 521; New College Oxford, MS. 3691 ff. 92-92v.

14 PRO, C270/22 mm. 1-2, 4. One of the most serious charges levelled against the master of St Thomas's, Southwark, in 1536, was that of refusing charitable relief to the poor and turning away any sick people who could not pay his exorbitant rate of charges (Letters and papers foreign and domestic, Henry $V I I I$, op. cit., note 9 above, vol. 11 , no. 168).

15 PRO, PCC Logge 2 (will of John Don of London, mercer). 


\section{The hospitals of later medieval London}

Cross lay the more celebrated house of St Mary Rouncivall. ${ }^{16}$ If we include a home for the deranged which was kept up in the same area until about 1377, this brings our total of working institutions up to thirty-four, approximately one-third of which were founded after 1300 (see Appendix). All but a few were comparatively small in size, offering accommodation for less than a score of people, and discharging one or more of the functions that have already been described; but there were in addition a number of specialist establishments for the care and forcible isolation of lepers, which merit separate consideration. Almost a third of the city hospitals, particularly those of earlier date, either followed or were very much influenced by the Augustinian rule, strictly religious observances being performed by regular canons, while the domestic or charitable work fell to the lot of lay brothers and professed sisters. There was a sound practical reason for this, since the Augustinian order was one of the very few which could accommodate the secular needs of the hospital. Not only was the burden of spiritual duties imposed upon its members far lighter, thus leaving more time for the care of the sick; but there was also a distinct emphasis upon the need for involvement in society. Even when, as so often happened in London, the founder was a layman and a merchant to boot, he still tended to impose the Augustinian rule upon his creation, or else to draw heavily upon it. The mercer, William Elsyng, initially intended his hospital near Cripplegate to be run by secular clergy, but in 1340, just nine years after its foundation, he changed his mind, and obtained a licence from the Bishop of London to convert it to a house of Augustinian canons. These latter, he hoped, would be less easily diverted by the affairs of the world, and more committed to the ideal of Christian charity. Like so many of his fellow-citizens, Elsyng was motivated by a complex mixture of genuine altruism, civic and personal pride, and a desire to ensure for himself a speedy passage to heaven by virtue of his good works. Yet it would be unduly cynical not to recognize the extent of his concern for suffering. "My very bowels", he wrote, "are torn with compassion (viscera mea gravius torquentur) for those priests who are left poverty-stricken and wretched because of blindness or paralysis"; and it was indeed to these men that he offered practical help. ${ }^{17}$ Elsyng was but one of many affluent city merchants whose philanthropy made possible the establishment and continuance of the greater proportion of London hospitals. Other benefactors included Thomas Fitztheobald and his wife, the sister of Thomas à Becket, who founded the hospital of St Thomas Acon in Cheapside in memory of the saint; Walter and Rosia Brune, upon whose land the house of St Mary's in Bishopsgate was built; and Simon Fitzmary, an alderman and some-time sheriff of London, now remembered as the first patron of St Mary's Bethlehem. During the fifteenth century, most new endowments were almshouses for the care of destitute or aged Londoners, the moving spirits here being the executors of Richard Whittington, whose foundation of 1424 was used as a model by, among others, the skinner, Henry Barton, and the draper, Sir John Milbourn, both of whom also wished to help honest tradesmen who had fallen upon illness or hard times. Although they were in a general sense influenced by the Augustinian rule, these houses were run by

\footnotetext{
16 David Knowles and R. Neville Hadcock, Medieval religious houses of England and Wales, London, Longman Group, 1971, pp. 342, 465, 393, 402.

${ }^{17}$ William Dugdale, Monasticon Anglicanum, ed. John Caley, Henry Ellis and Bulkeley Bandinel, 6 vols., London, Longman, 1817-1830, vol. 6 (part 2), pp. 703-708.
} 


\section{Carole Rawcliffe}

secular priests or chaplains, and were subject to the overall supervision of either the mayor or the members of a particular guild. ${ }^{18}$ Whether we see this development as a reaction by the city fathers against the marked decline of standards in several existing monastic hospitals, of which St Mary's Bethlehem was the most notable (see below), or simply regard it as evidence of that growing sense of corporate responsibility that also led at this time to the systematic improvement of London's water supply and prompted early legislation on public health and sanitation, the fact remains that throughout the later middle ages the provision and maintenance of hospitals was a matter of great interest to the laity.

Another recurring problem that obliged the civic authorities to take practical steps on their own account was that of leprosy; for although the disease became less prevalent during the later middle ages, it was still a cause of concern in the larger towns and cities of England. London possessed ten leper hospitals, strategically placed in a ring around the City. Three of these - at Kingsland near Hackney, at Mile End and at Knightsbridge - were actually founded by the mayor and aldermen. The origins of the Lock beyond Southwark are now obscure, but this too passed into the hands of the corporation and like the others was supervised by elected wardens. ${ }^{19}$ The latter were excused the customary round of civic duties because it was necessary for them "to go to the said places from day to day, to oversee the lazars and their houses there, and the rule and governance of the same, and to chastise and punish offenders against their rule, according to their deserts, as from old has been their usage." 20 In view of the strict, uncomfortable and isolated conditions under which they had to live, it is hardly surprising that many lepers staunchly resisted all attempts to remove them from the streets of London. Indeed, the general decay and impoverishment of leper hospitals throughout the country at this time is not so much a sign of the gradual disappearance of the disease - despite the fact that it was by then on the retreat - as the effect of a combination of other negative factors, of which scanty resources, maladministration, and draconian discipline were the most telling. Some new lazar houses were actually founded during the late fourteenth and early fifteenth centuries, but the problem of endowment remained a constant worry. Because of diminished funds, many established hospitals became almshouses, inevitably with reduced facilities and fewer inmates. The house of St Giles near London had, for example, been originally endowed by Queen Matilda in 1101 for the support of forty lepers, but by the Reformation it accommodated no more than fourteen paupers. ${ }^{21}$ The hospital of St James, a foundation for leprous women set up in the fields of Westminster in the reign of

\footnotetext{
18 Ibid., pp. 621-622, 645; Victoria county history of London, op. cit., note 8 above, pp. 520-554; Corporation of London Record Office, husting roll 166/46. For the earliest English text of the ordinances of Whittington's almshouses, see Jean Imray, The charity of Richard Whittington, London, Athlone Press, 1968, pp. 109-121.

19 Marjorie B. Honeybourne, 'The leper hospitals of the London area', Trans. Lond. Middx Archaeol. Soc., 1967, $21: 4-54$.

${ }^{20}$ Henry T. Riley (editor), Memorials of London and London life, London, Longmans, 1878, pp. 510-511. See also Reginald R. Sharpe (editor), Calendar of letter books of the City of London, I, London, John Edward Francis, 1909, p. 184, and K, 1911, pp. 142-143.

${ }^{21}$ Margaret A. Seymour, 'The organization, personnel and function of the medieval hospital in the later middle ages', London University, unpublished MA thesis, 1946, pp. 70-73; Dugdale, op. cit., note 17 above, pp. 635-636.
} 


\section{The hospitals of later medieval London}

Henry III with the help of a group of charitable Londoners, manifested all the ills to which such institutions fell victim, from poverty to dissension and disobedience to the misappropriation of funds. It came under the jurisdiction of the Bishop of London rather than that of the civic authorities, which may well account for some of its problems. Visitation records refer repeatedly to violent quarrels, unseemly noise, swearing, drunkenness, and sexual incontinence on the part of the brethren; and there can be little doubt that St James's, like so many similar establishments, had become caught in a downward spiral of penury, disorder, and misgovernment. ${ }^{22}$ Given these unhappy circumstances, sufferers from leprosy were generally left unmolested if they remained in seclusion, but steps continued to be taken against the open display of symptoms which society still held to be extremely contagious. Proclamations for the expulsion of lepers from London were made frequently during the later middle ages, both by the civic authorities and, when they proved ineffective, the monarch himself. ${ }^{23}$ The statutes of almshouses and general hospitals founded during this period manifest similar concern for the detection and removal of lepers, who, in some cases, were classed along with lunatics, epileptics, and pregnant women as being dangerously disruptive. The founders of Whittington's almshouse were especially careful to avoid the admission of those "infecte with lepre or eny suche other sikenesse intollerable", although anyone who succumbed to the disease while in residence was to be supported by the house in a suitable institution for the rest of his life. The statutes of the Savoy hospital for the poor, drawn up in, or before, the autumn of 1515 , required that preference should be given to the sick, but they likewise categorically barred lepers. ${ }^{24}$

This leads us to ask what kind of treatment sick paupers in general could expect once they entered hospital. Standards of care varied immensely from one foundation to another, but it is evident that few patients would have had much, if anything, to do with professionally trained physicians or surgeons. The latter confined their attention almost exclusively to fee-paying clients whom they visited in their own homes; and medication was often extremely expensive. Richard Il's physician, John Middleton, was retained at an annual fee of one hundred marks, while William Bradwardyne, the surgeon who accompanied him on his 1394 expedition to Ireland, later submitted a bill for $£ 66.13 \mathrm{~s} .6 \mathrm{~d}$. for medicine and travelling expenses alone. ${ }^{25}$ Both men showed a healthy respect for the economic forces of supply and demand, as did John of Arderne, one of the leading surgeons of the mid-fourteenth century, who warned his colleagues to be "warre of scarse askyngis, ffor ouer scarse askyngis setteth at not both the markette and the thing". Although they could not command the annuities of $£ 40$ or

${ }^{22}$ Victoria county history of London, op. cit., note 8 above, pp. 542-545.

${ }^{23}$ Clay, op. cit., note 2 above, pp. 53-54, 60-61; Calendar of close rolls, 1346-1349, London, HMSO, 1905, pp. 54, 61; Reginald R. Sharpe (editor), Calendar of letter books of the City of London, G, London, John Edward Francis, 1905, pp. 217, 301, and K, 1911, pp. 102-103.

${ }^{24}$ Imray, op. cit., note 18 above, p. 118; Robert Somerville, The Savoy, London, The Chancellor and Council of the Duchy of Lancaster, 1960, p. 30. For a similar example outside London, see Henry C. Maxwell-Lyte and Michael C. B. Dawes (editors), The register of bishop Beckyngton, Somerset Record Society, 1934, vol. 49, pp. 228-230.

${ }^{25}$ Calendar of patent rolls, 1396-1399, London, HMSO, 1909, p. 266. PRO, E101/402/20 f. 40. Thomas Morsted, a surgeon who accompanied Henry $\mathrm{V}$ to France in 1415, became one of the richest men in London with an income conservatively estimated at £154 p.a. from land alone (E101/69/409; Carole Rawcliffe, 'Medicine and medical practice in later medieval London', Guildhall Studies in London History, 1981, 5: 21). 


\section{Carole Rawcliffe}

more which practitioners like Arderne felt to be their due, men of lesser talent were equally reluctant to treat anyone who could not pay them promptly in cash. ${ }^{26}$ Yet surgeons must, occasionally, have been brought in to care for hospital patients, since from the early thirteenth century onwards priests and monks alike were forbidden to perform any treatment which involved the shedding of blood. ${ }^{27}$ A rental of St Mary's Elsyngspital, compiled in 1448, for instance, records sums of $37 \mathrm{~s} .2 \mathrm{~d}$. and $10 \mathrm{~s}$. owed, respectively, to Robert Leech and Geoffrey the Barber - it being common for surgeons and bloodletters to work together in partnership. ${ }^{28}$ One of the bequests made by the mercer, John Don, in 1479, is particularly instructive in this regard. A cash sum of $£ 25$ was to be set aside out of his estate so that the surgeon, Thomas Thorneton, could continue for the next five years "in his daily besynes and comfort of the poure, sore and seke peple lakkyng helpe and money to pay for their lechecraft in London and the subarbes of the same. In especiall in the hospitalles of Seint Mary, Saint Bartholomewe, Saint Thomas, Newgate, Ludgate and in other places, whereas peple shal have nede." 29 The testator was only too well aware that Thorneton might prove "slouthfull and nott diligent to attende the pour peple", so he made provision in this event for his replacement by a practitioner with a more active social conscience. The Tudor polemicist, Henry Brinklow, was no less perturbed about this continuing state of neglect, for which he held the government responsible. His proposal, voiced with evangelical forcefulness in about 1542, was that revenues diverted from the Church should be set aside for the establishment of proper medical facilities in every town with a hospital, "phisicyans and surgeons ... to lyue upon their stipend only, without taking any peny of there pore, vpon payne of losing both his earys and his stypend also." ${ }^{30}$

The mastership of several London hospitals lay in the king's gift, and it was therefore not uncommon for royal clerks who were also trained physicians to obtain these posts as a reward for their services. None the less, those few who were not already noted pluralists were rarely disposed to spend their time looking after sick or demented paupers when there were richer pickings to be had at court. The distinguished physician, John Arundel, seems at first sight to have been an ideal choice as master of St Mary's Bethlehem, since he was one of the five doctors chosen in 1454 to care for Henry VI during his severe bout of mental illness, but he held office only briefly before going on to become Bishop of Chichester. John Denman, one of his successors, obtained the mastership in 1494, "in consideration of his services to the King's mother", and was consequently far too preoccupied both with his royal patient and his duties as keeper of the college chest at Peterhouse to give much attention to

\footnotetext{
${ }^{26}$ Johannes Arderne, Treatise of fistula in ano, ed. D’Arcy Power, Early English Text Society, 1910, original series 139: 5 .

${ }^{27}$ The eighteenth canon of the Lateran Council of 1215 established that no cleric should in any way be involved in bloodshed, specifying thast "Nullus quoque clericus ruptariis uel balistariis aut huiusmodi uiris sanguinum preponatur, nec illam chirurgie partem subdiaconus, diaconus aut sacerdos exerceat que ad ustionem uel incisionem inducit". (Antonius Garcia y Garcia (editor), Constitutiones Concilii quarti Lateranensis una cum commentariis glossatorum, Vatican City, Biblioteca Apostolica Vaticana, 1981, p. 66.)

28 BL, Cottonian charter XIII 10.

29 PRO, PCC Logge 2.

$30 \mathrm{~J}$. Meadows Cowper (editor), Henry Brinklow's complaint, Early English Text Society, 1874, extra series 22: 52 .
} 


\section{The hospitals of later medieval London}

the lunatics in his charge. ${ }^{31}$ Some masters and wardens justified their conduct on the grounds that by keeping on a rich practice they secured influential support for the hospital as well as making money to supplement much-needed funds, but however they may have excused it, their absenteeism deprived the patients of medical attention and also contributed to a general decline in administrative and disciplinary standards. ${ }^{32}$ This was not, of course, always the case. During the fourteenth century, St Bartholomew's was the home of that eminent scholar and physician, John Mirfield, who lived there as a pensioner while composing his Brevarium Bartholomei, a substantial medical treatise covering the whole of medicine and surgery as they were then known, and also including sections on pharmacology and the regimen of health. Some passages seem to have been written from practical experience in the hospital and observation of the pharmacy, where complex remedies were prepared by the brethren who, if not trained physicians, were, none the less, men of considerable medical skills. ${ }^{33}$

The first London hospital to make specific provision for the regular attendance of surgeons and physicians upon patients was the Savoy, which was lavishly endowed by Henry VII and formally founded by his executors in 1515. However generous they may have been, men like Whittington and Elsyng simply did not possess the resources to pay the salaries of permanent medical staff, whereas the king was determined to spare no expense in the realization of his ideal. The staff of the Savoy was, consequently, to include two "honest men" skilled in, respectively, medicine and surgery, whose duty was to visit the sick each morning and afternoon when necessary. Probably with these rules in mind, the draftsman of regulations for an almshouse planned for sixty-six ill and destitute Londoners by Henry VIII just after the Reformation made similar arrangements for the employment of "on expert ffysicion" and "on expert surgeon". With a salary of $£ 20$ a year, the physician was allocated rather more than his colleague, but both men were expected to "geve daylie attendaunce and vysite the said poore seke and soore peopull two tymes in the day at lest, shewing and mynistring unto themme all thinges necessarie for their maladie". An apothecary was to receive $£ 10$ a year for accompanying the two doctors on their rounds and making up their prescriptions, while a further $£ 20$ was set aside annually "for the provision of drugges, gumes, aromates and other necessaries and instrumentis mete for ffysyke and surgerie". ${ }^{34}$ It should not, however, be assumed that the individuals who had hitherto been deprived of professional care inevitably suffered as a result. Medieval man must surely have survived illness and injury in spite, rather than because, of the ministrations of doctors, whose remedies were often guaranteed to weaken, if not seriously harm, their patients. Sick paupers were at least spared the continuous round of purging, bloodletting and noxious potions administered to their more affluent contemporaries. Agnes Paston was certainly convinced that both her husband and her

\footnotetext{
${ }^{31}$ Charles H. Talbot and Eugene A. Hammond, The medical practitioners in medieval England, London, Wellcome Historical medical Library, 1965, pp. 115-116, 339-340.

${ }^{32}$ See, for example, Calendar of patent rolls, 1348-1350, London, HMSO, 1905, pp. 175-176; Calendar of inquisitions miscellaneous, 7 vols., London, HMSO, 1916-1969, vol. 3, no. 6.

${ }^{33}$ Norman Moore, The history of St. Bartholomew's hospital, 2 vols., London, Arthur Pearson, 1918, vol. 1, pp. 608-611; Royal Commission on Historical Manuscripts, sixth report, London, HMSO, 1877, (part 1) p. 550.

${ }^{34}$ Somerville, op. cit., note 24 above, pp. 29, 32; PRO, El35/8/48 ff. 3-3v.
} 


\section{Carole Rawcliffe}

uncle had been killed by leechcraft. "For Goddys sake", she warned her son, "be ware what medesynys ye take of any fysissyanys of London. I schal neuer trust to hem".35 In many cases, therefore, the patient who was left alone in a clean and tranquil environment with good basic nursing and nourishing food stood a far greater chance of recovery. In point of fact, the absence of financial and organizational ability on the part of the wardens and masters of several London hospitals posed far more of a threat to the welfare of their charges than the lack of proper medical training.

Since little, if anything, was done to achieve uniform conditions in London's thirty or so pre-Reformation hospitals and almshouses, few generalizations can be made about standards of hygiene, diet, and supervision. The importance of fresh water and adequate drainage was certainly recognized, and where possible care was taken to ensure that the actual location of the hospital did not present a hazard in itself. After the original infirmary of St Thomas in Southwark was destroyed by fire in 1213, the house was moved to a temporary site and then, on the insistence of the Bishop of Winchester, to another. where the water was purer and the air healthier (ubi aqua est uberior et aer est sanior). ${ }^{36}$ Monastic institutions tended to lead the van in matters of sanitation and water supply; and it is therefore not surprising to find that piped water was introduced into some of London's hospitals a few years before the civic authorities began to contemplate such a move for the populace as a whole. In 1277, for example, the Bishop of London gave St Mary's Bishopsgate a spring at Stepney and permitted the brethren to divert it by underground pipes to the hospital infirmary for "the recreation, refreshment and profit of the poor".$^{37}$ Cleanliness was certainly an ideal towards which most authorities aimed, even if they sometimes fell far short of the mark. The nurses at St Katherine's by the Tower were warned in 1351 against the cultivation of inner purity at the expense of personal hygiene; and at the hospital of St Augustine Papey, which was in effect more of a rest home for old and sick priests, a married couple were engaged to keep the house clean and attend to the laundry. ${ }^{38}$ Each of the hundred poor men admitted nightly to the Savoy had to undergo a formidable ritual designed to purify the body as well as the soul, their physical wholesomeness being secured by the provision of hot baths, delousing ovens for their clothes, and freshly laundered dressing gowns resplendent with the Tudor livery (even the counterpanes on their beds were thus emblazoned so that they might be in no doubt as to the identity of their benefactor). ${ }^{39}$ Nuisances of various kinds could, none the less, render a stay in hospital less salubrious. The much-vaunted pure air of St Thomas's was contaminated during the late fourteenth century by the noise and smells proceeding from artisans' workshops in the hospital precincts, while St Mary's Bethlehem possessed a herd of pigs that were left free to root around the infirmary. The patients here appear to have suffered very badly during this period, as the deputy warden augmented his income even further by running an alehouse on the premises

\footnotetext{
${ }^{35}$ Norman Davis (editor), Paston letters and papers of the fifteenth century, 2 vols., Oxford, Clarendon Press, 1971-1976, vol. 1, no. 177.

${ }^{36}$ Victoria county history of London, op. cit., note 8 above, p. 538.

${ }^{37}$ Royal Commission on Historical Manuscripts, ninth report, London, HMSO. 1883, (part 1) p. 29.

36 Jamison, op. cit., note 9 above, p. 29; Thomas Hugo, 'The hospital of Le Papey in the City of London', Trans. Lond. Middx Archaeol. Soc., 1877, 5: 187.

39 Somerville, op. cit., note 24 above, p. 31 .
} 


\section{The hospitals of later medieval London}

where he entertained his friends until late into the small hours..$^{40}$

The first hint that the Bethlehem hospital had begun to admit the severely deranged as well as the sick and destitute occurs in the mid-1370s, when it seems likely that a group of violently insane persons who had previously been kept under lock and key outside the City, near what is now the site of St Martin's-in-the-Fields, were transferred to the hospital, perhaps because members of the royal court were disturbed by their proximity. ${ }^{41}$ There was obviously a growing need at this time for the establishment of a house devoted, in part at least, to the care of lunatics, as in the same decade a clerk named Robert Denton launched a plan for an institution which would cater exclusively for "poor priests and other men and women who had fallen into frenzy and lost their memories and where they could remain until cured and restored to sanity". Denton's plans came to nothing when the site of his proposed asylum was sold to another bidder, but his decision to shelve the project may also have been influenced by the sudden development of Bethlehem, a comparatively wellestablished institution, as an alternative centre for the custody of the mentally ill.42 Certainly, by 1403, the hospital possessed six chains with locks and keys, four pairs of manacles of iron, five other chains of iron, and two pairs of stocks, all of which seem to have been used to restrain the violent. Some fifty years later, Bishop Bekyngton of Bath and Wells referred specifically to the "multitude of miserable persons of both sexes dwelling there, who are so alienated in mind and possessed of unclean spirits that they must be restrained with chains and fetters", so by this date the practice was commonplace. ${ }^{43}$

The organization and layout of the medieval hospital was largely determined by its primary function, which was not the care of the sick per se, but the service of God through healing. The salvation of the body came a very poor second to that of the soul; and it was, moreover, believed that sick men and paupers had a Christian duty to spend their time in hospital praying for the souls of others. This idea accorded most conveniently with a second tenet of dogma, namely that the passage of the soul through purgatory might be hastened by the intercessionary prayers of the living: and it is thus hardly remarkable that founders and benefactors made religious observance a prerequisite of admission. The inmates of Milbourn's almshouse were, for instance, to recite at eight o'clock every morning the psalm de profundis and a paternoster, ave, and creed, with the appropriate collect for the salvation of their patron; and an even more strenuous burden of devotions was imposed upon those who sought refuge at Whittington's almshouse. In addition to daily attendance at "matyns, masse, evensong, complen and other houres of holy Chirche", they were to say special prayers for the souls of the late mercer and his wife immediately on rising in the

\footnotetext{
${ }^{40}$ New College Oxford, MS. 3691 f. 91v; Calendar of patent rolls, 1388-1392, London, HMSO, 1902, p. 484; PRO, C270/22 m. 2. St Anthony's must have kept pigs too, as the hospital was entitled to claim any pig which the supervisors of the city markets thought unfit to be killed for food. The beasts were fattened by the citizens as a work of charity and then given to the brethren (Victoria county history of London, op. cit., note 8 above, p. 581).

${ }^{41}$ Edward G. O'Donoghue, The story of Bethlehem hospital, London, T. Fisher Unwin, 1914, pp. 66-68.

42 This was to have been the hospital of Barking Church near the Tower, licensed in 1370 (Calendar of patent rolls, 1377-1381, London, HMSO, 1895, p. 266; Thomas (editor), op. cit., note 5 above, p. 23).

${ }^{43}$ PRO, C270/22 m. 3; Maxwell-Lyte and Dawes (editors), op. cit., note 24 above, p. 59.
} 


\section{Carole Rawcliffe}

morning and just before retiring at night. Any idle moments not thus accounted for were to be spent in the recitation of "iij or ij Sauters of oure Lady atte ye leest that is to seie thries I Ave maria with xv pater noster and iij Credes", the seriously ill alone being excused this treadmill of pious gratitude. ${ }^{44}$ Almost all hospital infirmaries were situated in the naves of churches, partly for convenience, because this was the largest area available, but also so that the bedridden could see the altar and thus take part in services. In the case of the Savoy, which was modelled on the Florentine hospital of Santa Maria Nuova, the dormitory was a great cruciform structure with cubicles in the north and south transepts as well, although this was a radical departure from the traditional English pattern. ${ }^{45}$ Here, as in many earlier foundations, each of the inmates enjoyed the privacy of a separate cubicle furnished with a bed and all the necessary linen and blankets. The founders of Whittington's almshouse laid particular stress on the need for seclusion as an aid to prayer, reading, and meditation; and the statutes of Elsyng's hospital made similar arrangements for the equipment of private cells. The infirmary of St Mary's Bishopsgate, on the other hand, was set out as an open ward with the unusually large number of about 180 beds, each of which was illuminated with its own lamp, although the brethren were sometimes rather careless about keeping these alight. Gifts of money to provide adequate lighting (which enabled the sick to look upon the altar even at night) were by no means uncommon. One such grant was made to St Thomas's in Southwark during the late thirteenth century, and in 1415 a Chichester man donated two more lanterns which were to be hung over the beds of the poor. ${ }^{46}$ William Gregory records how "that nobyl merchaunt", Richard Whittington, endowed a separate ward there "with viij beddys for yong weme that hadde done A mysse in truste of a good mendement", and although he is our only authority for such a reputed act of charity on the mercer's part, St Thomas's would certainly have been the ideal choice of hospital for anyone wishing to help unmarried mothers, since it was situated near the stews at Bankside.97

Whenever possible, patients were expected to bring with them their own blankets and linen, which were retained and used again if they died on the premises. A substantial quantity of the basic equipment owned by the Bethlehem hospital was acquired in this way. "A certain man from Westminster", for example, contributed "one cover, two blankets, two pairs of linen sheets, one matress, one pillow and one chest", all of which became the property of the authorities on his death. ${ }^{48}$ Gifts from charitable patrons did much to make the life of the destitute more tolerable, since it was common for pious Londoners to bequeath sums of money or rents for the purchase of specific items such as fresh linen, warm clothes, or extra food. In about 1215, Alexander de Norfolk left a house to St Bartholomew's Hospital so that the revenues might be used to provide shelter for the poor and linen sheets for the

\footnotetext{
4 Thomas Milbourn, 'The Milbourn alms-houses and a brief account of the founder and his family', Trans. Lond. Middx Archaeol. Soc., 1870, 3: 138-152, see p. 140; Dugdale, op. cit., note 17 above, pp. 739-747; Imray, op. cit., note 18 above, pp. 115-116.

as Howard M. Colvin (editor), The history of the King's works, 6 vols., London, HMSO, 1963-1973, vol. 3 (part 1), 1485-1660, pp. 198-199.

to Dugdale, op. cit., note 17 above, pp. 623-626, 704-707, 744-747; Victoria county history of London, op. cit., note 8 above, pp. 530-534; BL, Stowe MS. 942 ff. 99v, 106v.

${ }^{47} \mathrm{BL}$, Egerton MS. $199 \mathrm{f}, 86 \mathrm{v}$.

4 PRO, C270/22 mm. 2-3.
} 


\section{The hospitals of later medieval London}

infirmary; and other benefactors at this time made possible the unaccustomed luxury of white bread on special occasions. ${ }^{49}$ Few bequests were as lavish as the $£ 100$ left by Robert Chichele, a former mayor, in 1438, to supply bread and ale to "the lepers, infirm, poor and lunatic" of five major London hospitals, but when sums of this size were involved the possibility of misappropriation or even fraud was also much greater..$^{50}$ A combination of poverty, maladministration, ignorance, and occasionally even downright dishonesty led some houses to economize on the quality and quantity of food distributed among the infirm, even though it was clearly understood that the sick and feeble required a special diet. ${ }^{51}$ Having inspected the hospital kitchens at St Thomas's, Southwark, in 1387, the Bishop of Winchester pronounced the food dangerously inadequate and ordered the master to supply more nourishing fare under pain of immediate suspension. ${ }^{32}$ Against this must, however, be set the example of St Anthony's Hospital, which went in for gourmandizing on a particularly lavish scale, perhaps because of the profitability of the school. On Easter Sunday 1495, an assembly of sick paupers, homeless beggars, scholars, and brethren consumed four lambs, seven capons, a hundred eggs, eighteen chickens, half a veal, and three gallons of claret - the master's table dining separately off two green geese and six rabbits. Neither, as the surviving accounts show, was this impressive cuisine confined to high days and holidays. ${ }^{33}$ Hospitals whose endowment included estates outside London were particularly fortunate because until the transition from demesne farming in the late fourteenth century they could arrange for the supply of fresh produce from tenants, and thus avoid the outlay of much-needed capital in the city markets. Several of the leases negotiated by St Bartholomew's Hospital with the farmers of its property in Essex during the thirteenth and fourteenth centuries specified that part of the rents were to be paid in kind, usually either grain or stock..$^{54}$ An alarming tendency elsewhere, however, was the substitution of meals by a dole in the form of cash or tokens redeemable for food from private vendors. Although this practice lightened the burden of the authorities, it opened the door to a host of abuses, and was yet another departure from the ideal of a concerned and caring community. ${ }^{55}$

The evidence of hospital visitations, which are our main source of information about nursing, likewise provides a somewhat depressing picture of growing indifference, lost vocation, and declining standards. It is, of course, important to maintain a sense of perspective when using these records, but there can be little doubt that the sisters who undertook to care for the sick in London's hospitals were, like their counterparts throughout England, frequently a cause of both concern and

\footnotetext{
49 Kerling (editor), op. cit., note 7 above, pp. 9, 64, 80. For similar examples see the wills of Stephen Foster (1458) and John Don (1479), who left, respectively, $£ 10$ and $£ 136 s$. 8d. to supply food, drink, linen, and woollen clothing for "the poure seke peple of Bethlehem" (Frederic W. Weaver (editor), Somerset medieval wills, 1383-1500, Somerset Record Society, 1901, 16: 181-182; PRO, PCC Logge 2).

so Ernest F. Jacob (editor), The register of Henry Chichele, 4 vols., Canterbury and York Society, 1937-1947, vol. 2, p. 567.

s1 The foundation statutes of Whittington's almshouse, for example, specified that if an inmate fell ill he was to be provided with "a suitable diet out of his weekly pension" (Calendar of patent rolls, 1429-1436, London, HMSO, 1907, p. 215).

32 New College Oxford, MS. 3691 f. 92.

s3 Victoria county history of London, op. cit., note 8 above, p. 583, note 39.

${ }^{34}$ Kerling (editor), op. cit., note 7 above, pp. 10-12.

ss Seymour, op. cit., note 21 above, pp. 94-95.
} 


\section{Carole Rawcliffe}

dissatisfaction to their superiors. To make matters worse, they were sometimes treated badly by the brethren on account of their lowly position and menial duties. In the early fourteenth century, the sisters at St Bartholomew's were allocated meagre quantities of inferior food, which may explain why they, at least, were neglecting their obligations towards the sick. A similar state of affairs came to light, in 1431, at St Mary's Bishopsgate, where the seven grossly overworked sisters were being deprived of adequate clothing as well as proper diet. However deplorable this may have been, the Bishop of London was far more concerned about the fact that sisters and brothers were consorting illicitly in the kitchens. He promptly ordered the construction of a closed way to keep the two sexes segregated; and he also insisted that any new recruits to the sisterhood should submit to a year's probation before taking their vows. ${ }^{56}$ Cases of flagrant immorality did indeed occur from time to time, but the chief problem in London's monastic hospitals was laxity rather than fornication. Over and over again, visiting authorities were obliged to remind both brothers and sisters of their sacred duty to tend the sick and visit them daily as a work of piety. Hospitals were evidently no more immune from the changing religious climate than other enclosed institutions, which, with certain exceptions, were experiencing a perceptible decline, both spiritually and economically.

Whether or not the inmates of the civic leper hospitals fared any better as a result of the appointment of laymen to oversee the care of the sick, we shall never know, but the introduction of one such supervisor by the civic authorities at St Mary's Bethlehem in the 1430s certainly appears to have proved successful. ${ }^{37}$ As early as 1346 the financial and administrative affairs of the house were in such an appalling state that the master was driven to approach the mayor and aldermen for help and protection. His petition was quite obviously intended to exploit that growing sense of civic awareness and interest in public health which had already led to the foundation of at least three publicly owned lazar houses, and which was then also prompting men like William Elsyng to help those less fortunate than themselves. The appeal did not fall upon deaf ears, and, in October 1346, a formal agreement was drawn up whereby two aldermen were to be chosen each year to act first as governors of St Mary's and afterwards as members of a permanent tribunal or management committee. ${ }^{38}$ Their powers were sweeping, and had they been properly implemented for a reasonable period it seems likely that stability, if not affluence, would have been assured. Richard II's insistence upon complete rights of patronage and supervision led, however, to the appointment of absentee masters and an all too predictable return to corruption and negligence. The effects of this were long-lasting, and even after the reintroduction of civic control in the second or third decades of the fifteenth century, the master felt it was almost impossible to continue "with the worship of God, and alms and other

\footnotetext{
56 Victoria county history of London, op. cit., note 8 above, pp. 521, 532-533.

${ }^{37}$ Sharpe (editor), $K$, op. cit., note 23 above, p. 194. On 20 April 1436, William Mawere, tailor, was excused his other civic duties because of his "constant attention to the poor mad inmates of the hospital of St. Mary de Bethlehem".

s3 Sharpe (editor), op. cit., note 23 above, F, 1904, pp. 154-155; O'Donoghue, op. cit., note 41 above, pp. 37-44. The civic authorities were used to dealing with problems of hospital administration. In 1327, for example, Edward III commissioned them to survey the house of St Thomas of Acon "and to amend deffects as often as necessary" (Calendar of patent rolls, 1327-1330, London, HMSO, 1891, p. 58).
} 


\section{The hospitals of later medieval London}

works of piety and the succour of demented lunatics and other poor and sick persons". ${ }^{9}$ Even so, thanks to a concerted effort on the part of the brethren and the city fathers, by the 1450 s, the chronicler, William Gregory, was able to report considerable improvements, noting with evident approval that even the incurable were kept "fulle honestely there". ${ }^{60}$

The trials and tribulations of St Mary's provide a telling - if rather extreme example of the difficulties faced by hospitals throughout England at this time. Concern was frequently expressed by the laity over the administration of revenues, which were often badly managed and sometimes even embezzled by dishonest officials. The Commons of the Parliament of April 1414 gave voice to this growing anxiety in a petition which drew attention to the malversation and wastage of resources. "Men and women have died", they protested, "for lack of aid, livelihood and succour to the displeasure of God and the peril of the souls of those who squander and misappropriate the goods provided for these unfortunates by others." ${ }^{161}$ Almost all of London's hospitals faced serious economic difficulties at some time or another during our period, not always as a result of peculation or incompetence. The fall in land values consequent upon the Black Death severely affected many institutions, as did over-ambitious building schemes that proved a virtual guarantee of financial ruin.62 The underlying problem lay, however, in the precarious nature of hospital funding, since only part of the income necessary for survival came from land or rents, the rest being totally dependent upon public charity. This was notably the case at the Bethlehem Hospital, where the abuses of the late fourteenth century merely exacerbated a problem inherent in the nature of the house's finances. Unlike some of its neighbours (which also regularly ran into debt), it derived only a small part of its receipts from property. Whereas at the Reformation St Bartholomew's could rely on $£ 305$ p.a. net from this source, St Thomas of Acon on $£ 277$ or more, and Henry VII's new foundation at the Savoy on at least $£ 529$, St Mary's expected profits of barely $£ 40$ from land, and that on an optimistic valuation drawn up by Wolsey's agents for taxation purposes. ${ }^{63}$ It was thus all the more reliant upon other, less regular kinds of income, of which donations and bequests were by far the most important. The chief crime of the deputy-warden, Peter the Taverner, who was indicted on several charges in 1403, was that of stealing alms and oblations in excess of $£ 304$ raised nationwide over a period of some thirteen years. ${ }^{64}$

Every city hospital sought desperately for such alms, which could be further augmented in several ways. The award of indulgences, either by an English bishop or by the Pope himself, to prospective benefactors usually prompted a sharp rise in donations. In 1389, for example, the Bishop of Lincoln promised an indulgence of forty

s9 Calendar of patent rolls, 1436-1441, London, HMSO, 1907, p. 87.

${ }^{\circ}$ Gairdner (editor), op. cit., note 7 above, p. ix.

61 Rotuli Parliamentorum, 6 vols., London, vol. 4, pp. 19-20, 80-81.

62 Victoria county history of London, op. cit., note 8 above, pp. 493, 536.

${ }^{63}$ Dugdale, op. cit., note 17 above, pp. 626, 646; Somerville, op. cit., note 24 above, p. 33; John S. Brewer (editor), Letters and papers foreign and domestic, Henry VIII, vol. 4, p. 964.

ot PRO, C270/22 mm. 1-2. Many such examples can be cited from other hospitals. In both 1324 and 1327, orders were given for the arrest of persons pretending to be proctors of the brethren of St Bartholomew's, who had made away with substantial amounts of money in their name (Calendar of patent rolls, 1324-1327, London, HMSO, 1904, p. 25, and 1327-1330, 1891, p. 18). 


\section{Carole Rawcliffe}

days to anyone providing support for "the host of weak, poor and homeless people" who flocked to the hospital of St Mary Rouncivall; and shortly afterwards, Pope Boniface IX granted one hundred days' remission of penance to those who visited St Anthony's Hospital with the purpose of giving alms. ${ }^{65}$ Proctors appointed by each of the major London houses meanwhile travelled the length and breadth of England seeking gifts from potential donors, who duly received the appropriate number of spiritual credits. Another important aspect of lay piety manifested itself in the foundation of chantries, either for a period of years or in perpetuity, where prayers were said for the souls of the departed, their families and friends. Two houses settled upon the hospital of St Thomas Acon with this intent in the fifteenth century produced $£ 117 \mathrm{~s}$. $2 d$. a year, which left a clear income of seven guineas at the disposal of the authorities after the priest had been paid. ${ }^{66}$ Hospitals were thus very anxious to offer facilities for chantry chapels and private altars; and, on the whole, Londoners responded with great generosity. Unfortunately, rather less enthusiasm was shown for the upkeep and repair of the property thus acquired, with the result that anticipated revenues could not be maintained. By 1484, the comparatively rich house of St Mary without Bishopsgate found it impossible to continue its charitable work because the holdings in London upon which it depended had deteriorated so badly that expensive repairs could no longer be postponed. ${ }^{67}$

All the benefactions so far considered were personal acts of charity, but the desire to endow or otherwise help a hospital was by no means confined to private individuals. Several city guilds and fraternities developed a close attachment to particular institutions, sometimes because the founder had expressly wished them to do so, but often for less obvious reasons shrouded in the mists of time. Geographical proximity probably led both the Pouchmakers and Drapers to meet at the hospital of St Mary Bethlehem from the mid-fourteenth century onwards, but whatever the reason their presence and support were greatly valued by the brethren. ${ }^{68}$ The Mercers' connexion with Whittington's almshouse was clearly defined in the foundation charter, but their older and eventually closer relations with the hospital of St Thomas Acon developed gradually over many years. John Young's remarkable feat of paying off debts in the order of $£ 718$ within eight years of assuming the mastership in 1510, as well as finding an additional $£ 1,431$ for repairs and new buildings was attributed by the brethren to "divine providence and human industry", although in point of fact the deus ex machina who had so opportunely come to their rescue took the more prosaic form of a group of wealthy merchants. It was in 1514 that the Mercers' Company assumed the official role of defender and advocate of St Thomas's, demanding in return that detailed accounts should be submitted for their inspection every year. ${ }^{69}$ This was no new idea. Back in 1331, William Elsyng (who was also a mercer with a lifetime's experience of harsh economic reality) had insisted upon the need for annual audits as

\footnotetext{
${ }^{65}$ Lincolnshire Archive Office, Register Buckingham XII f. 357v; Victoria county history of London, op. cit., note 8 above, pp. 581-582.

${ }^{66}$ Royal Commission on Historical Manuscripts, ninth report, op. cit., note 37 above, p. 213; PRO, E135/2/57.

67 Victoria county history of London, op. cit., note 8 above, p. 533.

${ }^{68}$ Herbert F. Westlake, The parish gilds of medieval England, London, SPCK, 1919, p. 134.

${ }^{69}$ PRO, E135/2/57.
} 


\section{The hospitals of later medieval London}

both a deterrent against dishonesty and a means of exercising tighter control on expenditure. Even so, by 1438 , his hospital was almost $£ 430$ in debt, and it still owed over $£ 200$ ten years later. ${ }^{70}$ The monotonous regularity of complaints about lax or non-existent book-keeping in the reports of episcopal visitations suggests that unless they did have some outside help from experienced laymen many city hospitals were incapable of managing their affairs efficiently. ${ }^{11}$

Inevitably, as they became more and more involved in, and responsible for, the financing of their hospitals, these merchants and tradespeople began to expect a far greater degree of control over the way in which their money was being spent. We have already seen how, years before the Reformation, the mayor and corporation introduced lay supervisors into certain London hospitals, and it was natural that they should soon wish to extend their authority even further, especially in view of the exasperation which was clearly felt in many quarters over administrative incompetence. In 1523, the merchant tailor, Stephen Jennings, left $£ 40$ in his will towards the purchase price of St Mary's Bethlehem by the rulers of London; and although the hospital was not acquired by them outright until 1546, there had probably long been plans afoot for such a move. ${ }^{72}$ That the City desperately needed its refuges "for the ayde and comforte of the poore, sykke, blynde, aged and impotent persones, beyng not hable to help theymselffs" was brought home forcibly enough to those who had to deal with the horde of miserable wretches discharged from its hospitals at the Dissolution of the Monasteries. Yet, as Richard Gresham, the mayor, pointed out to Henry VIII in 1538 , the time was well overdue for the civic authorities to assume corporately a task in which they had long been involved as private persons. ${ }^{73}$

\section{SUMMARY}

Medieval hospitals performed a wide range of functions, which included the provision of hospitality for wayfarers and education for young children, often on a feepaying basis. Their main role, however, was the care of the sick, aged, and destitute. Ideally, they were supposed to provide this service free of cost as a Christian duty, but pressing economic circumstances often obliged the authorities to depart from this monastic precept, and many houses did impose charges in order to subsidize their charitable work. London possessed about thirty-four hospitals and almshouses during the later middle ages, most of which followed the Augustinian rule and owed their foundation and upkeep to the philanthropy of wealthy merchants. The mayor and aldermen were, moreover, responsible for running four of the City's ten leper hospitals, which were particularly subject to the problems of maladministration,

\footnotetext{
${ }^{70}$ Dugdale, op. cit., note 17 above, p. 705; BL, Cottonian charters XI 10, 68.

" For instance, in 1303, the Archbishop of Canterbury required proper accounts to be kept at the hospital of St Mary's Bishopsgate. Similar demands were made at St Thomas's, Southwark, by the Bishop of Winchester in 1387, and, most notably of all, by the royal commissioners who examined the affairs of the Bethlehem hospital in 1403 (Victoria county history of London, op. cit., note 8 above, pp. 521, 531; New College Oxford, MS. 3691 f. 92v; PRO, C270/22).

72 John Stow, $A$ survey of London, ed. Charles L. Kingsford, 2 vols., Oxford, Clarendon Press, 1908, vol. 1, pp. 164-165.

${ }^{73}$ John Strype, Ecclesiastical memorials, 3 vols., Oxford, Clarendon Press, 1822, vol. 1 (part 1), pp. $409-410$.
} 


\section{Carole Rawcliffe}

poverty, and lost vocation evident in so many English hospitals during the period. Conditions varied very much from one institution to another, but although few patients were attended by trained practitioners (whose services were very expensive), the need for cleanliness, proper nursing, good food, and a calm atmosphere was readily appreciated - even if practice sometimes fell short of theory. The people of London felt a keen sense of responsibility in matters of public health, and provided a great deal of financial support for their hospitals. Yet problems of absenteeism, lax discipline, precarious funding, and lack of administrative expertise seriously affected the working of many houses, which turned increasingly to the civic authorities for help with their organization.

\section{APPENDIX}

\section{THE HOSPITALS AND ALMSHOUSES OF LATER MEDIEVAL LONDON*}

Aldersgate Hospital: Order of Cluny. Suppressed by Henry V as an alien house. Refounded by William Bever as a brotherhood of the Holy Trinity. Revenues of $£ 18$ p.a. in 1548 (Ralph B. Pugh (editor), Victoria county history of Middlesex, 7 vols. to date, Oxford, Clarendon Press, 1969-1982, vol. 1, p. 204).

AlmShouse by St ANNE'S Hospital, WeStMinSTER: Founded by Lady Margaret Beaufort (d. 1509), mother of Henry VII, for poor women.

Almshouse by The Gatehouse of Westminster Abbey: Founded by Henry VII (d. 1509) for thirteen poor men, one of whom was to be a priest, while the others were to be unmarried.

ASKEW'S ALMSHOUSE: Founded by the widow of Sir Christopher Askew (mayor of London in 1533) for eight poor widows of members of the Drapers' Company (John Stow, Survey of London, ed. Charles L. Kingsford, 2 vols., Oxford, Clarendon Press, 1908, vol. 1, p. 302).

Domus Conversorum: Founded in 1232 by Henry III for Jews converted to Christianity. A staff of three chaplains (1267) and a school. Numbers fell from 100 (not all resident) in 1256 to eight in 1344.

Elsyng's SPITAl or St MaRY Without CRIPPlegate: Founded in 1331 by William Elsyng. Order of St Augustine from 1340. A staff of a prior and ten canons (1534) for the care of 100 sick paupers, preference to blind or paralysed priests. Revenues of $£ 193$ p.a. in 1535. Rules given in full by Dugdale in op. cit., footnote 17 above, vol. 6 (part 2), pp. 703-708.

\footnotetext{
* Unless otherwise stated, this list is based upon William Page (editor), The Victoria county history of London, London, Constable, 1909, pp. 520-554; and David Knowles and R. Neville Hadcock, Medieval religious houses of England and Wales, London, Longman Group, 1971, pp. 342, 365, 393, 402. A fully documented history and list of London's lazar houses is to be found in Marjorie B. Honeybourne, 'The leper hospitals of the London area', Trans. Lond. Middx Archaeol. Soc., 1967, 21: 4-54.
} 


\section{The hospitals of later medieval London}

FRATERNITY OF ST JOHN THE BAPTIST: Founded in c. 1405 by the grocer, John Churchman, for seven poor men with wives if married.

Grocers' Hall Almshouse: Founded in c. 1429 by Thomas Knolles and other leading members of the Grocers' Company for the relief of seven "aged poore Almes people" and the general support of destitute members of the company (Stow, op. cit., vol. 1, p. 263).

Jesus Commons: Possibly founded in the late fourteenth century. A corporate body of priests living together in Dowgate ward for mutual help and protection.

LA Reole HoSPICE: Granted to St Stephen's College, Westminster, in 1369.

Lombard Street Hospice: Granted to St Stephen's College, Westminster, in 1354.

MilbouRn'S AlmShouse: Founded in c. 1524 by Sir John Milbourn (d. 1535) for the relief of thirteen poor men with wives if marred (Milbourn, op. cit., footnote 44 above).

OUR LADY AND St KATHERINE, NEWINGTON: A small hospice possibly under the authority of St Bartholomew's hospital (q.v.); it still functioned in 1551.

St ANDREW'S PARISH, Holborn: Possessed a cell of the Cluniac order intended as a hospital for the poor, which, according to Stow (op. cit)., vol. 2, p. 39), was suppressed by Henry $\mathrm{V}$ as an alien house.

St ANTHONY: Founded in c. 1254 by the house of St Anthony of Vienne. Order of St Augustine. Staff of a master, two priests, and a schoolmaster for the care of twelve poor men, the succour of the sick poor generally, and the upkeep of a school, which became increasingly important. By 1522, its work was almost exclusively educational. Revenues of almost $£ 540$ p.a. in 1479.

St Augustine Papey: Founded in c. 1442 by three chaplains for the shelter and support of "poor impotent priests" belonging to the Fraternity of Charity and St John the Evangelist. A master and five priests lived there in 1535. Rules (BL, Harley MS. 604 ff. 12-12v; Cotton MS. Vittellius F xvi ff. 113-123v) summarized and partly transcribed by Hugo in op. cit., footnote 38 above, pp. 208-221.

St BARThOlOMEW: Founded in 1123 by Rahere. Order of St Augustine. Staff of a prior, seven brothers, and five sisters (1316) for the care of the sick poor, pilgrims, and wayfarers. Revenues of over $£ 305$ p.a. in 1535 .

St Giles Without Cripplegate: Founded as a Cluniac cell in the time of Edward I. Suppressed by Henry $V$ as an alien house and refounded by him as a fraternity for the relief of the poor.

St James Shoreditch or The Shoreditch Spital House: Listed by Clay in op. cit., footnote 2 above, p. 305, but not otherwise documented.

ST JOHN OF JeRUSALEM: Part of the priory of the Knights Hospitallers, but more of a guest house than a hospital or almshouse. 


\section{Carole Rawcliffe}

St KATHERINE BY THE TOWER: Founded in 1148 by Queen Matilda. Order of St Augustine. Staff of a master, brothers, and sisters for the care of thirteen poor persons. Refounded in 1273 by Queen Eleanor for a master, three brothers, priests, sisters, eighteen poor bedeswomen, and six scholars. Revenues of $£ 315$ p.a. in 1535 . Rules of 1351 given in full by Jamison in op. cit., footnote 9 above, pp. 28-32.

ST MARTIN-IN-THE-FIELDS: “Distraught and lunatike people" were reputedly kept in a "stone house" in this area until the late fourteenth century, when they were removed to St Mary's Bethlehem (q.v.). (See O'Donoghue, op. cit., footnote 41 above, pp. 66-72.)

St MARY'S BeThleheM: Founded in 1247 on land given by Simon Fitzmary. Order of St Mary of Bethlehem. Staff of a master, canons, brothers, and sisters in fluctuating numbers for the relief of the sick poor, but from the late fourteenth century, there was a growing specialization in the care of the insane. Revenues of about $£ 40$ p.a. in 1546.

St Mary Rouncivall, Charing Cross: Founded before 1231 by William Marshal, earl of Pembroke, as a cell of Roncevaux Abbey for the relief of the sick poor. Suppressed as an alien house by Henry V, who allowed the charitable work to continue. Became a fraternity in 1474 dedicated to the care of paupers.

St Mary Without Bishopsgate: Founded in 1197 by Walter and Rosia Brune. Refounded in 1235. Order of St Augustine. Staff of a prior, twelve canons, five brothers, and seven sisters (1303) for the care of the sick poor. Revenues of over $£ 504$ p.a. in 1535 , when the hospital had 180 beds.

St Paul's Hospice: Founded in c. 1190 by Henry de Northampton, a canon of St Paul's, within the precincts of the cathedral. For the sick and poor.

St Saviour, Bermondsey: Founded just after 1170, and endowed by, among others, the sister and nephew of Thomas a Becket.

ST Thomas of Acon: Founded in the time of Richard I by Thomas and Agnes Fitztheobald. Order of St Augustine. Staff of a prior and twelve brothers (1248, 1444) for the relief of the poor and sick. Revenues of $£ 277$ p.a. in 1535.

St Thomas the MARTYR, BermondSEy: Founded in 1213 by the prior of the local Cluniac monastery for boys and converted Jews.

St Thomas, Southwark: Founded by Thomas a Becket (d. 1170) within the precincts of the Augustinian priory for the care of the sick poor. Destroyed 1213. Refounded at once on a new site by Peter des Roches, Bishop of Winchester. Order of St Augustine. Staff of a master, four brothers, three sisters (1392). Revenues of $£ 309$ p.a. in 1535 , when the hospital had forty beds.

Savoy Hospital of THE Blessed Jesus: Founded in 1505 by Henry VII (d. 1509), completed by his executors in 1515. Staff of a master, four chaplains, two priests, four altarists, seven servants, a matron, and twelve sisters for the care of 100 poor men, preference being given to the sick, who were tended by a physician, a surgeon, and an 
The hospitals of later medieval London

apothecary. Revenues of over $£ 567$ p.a. in 1535. Statutes of 1524 (BL, Cotton MS. Cleopatra C v; summarized by Somerville in op. cit., footnote 24 above, pp. 27-32, 250-251.)

Westminster Palace HosPice: Granted to St Stephen's College, Westminster, in 1354.

Whittington's Almshouse: Founded in 1424 by the executors of Richard Whittington for thirteen poor people, preference being given to members of the Mercers' Company or retired clerks from Whittington College. Rules given in full by William Dugdale, op. cit., footnote 17 above, vol. 6 (part 2), pp. 738-747.

VINTNERS' Hall AlmShouseS: Founded by John Stody (mayor of London in 1358) for thirteen poor members of the Vintners' Company (Stow, op. cit., vol. 2, p. 106). 